\title{
PENERAPAN MODEL COOPERATIVE LEARNING TIPE JIGSAW DENGAN MEDIA GAMBAR UNTUK MENINGKATKAN AKTIVITAS DAN HASIL BELAJAR PADA PEMBELAJARAN MATEMATIKA SISWA KELAS IV SDN 2 NAMBAHREJO
}

\author{
Rusmartini \\ Guru SDN 2 Nambahrejo \\ Email: rusmartini1960@gmail.com
}

\begin{abstract}
The aims of this research were to increase the activities and the result of study by implementation of cooperative learning model type jigsaw with picture media. The method of the research was Classroom Action Reserach. The instrument of data collection used observation sheet and test. Technique of data analysis used qualitative and quantitative analysis. The result showed that the student activity in cycle I 62,58\% (active) and cycle II $81,50 \%$ (activeenough). The result study of the cognitivie in cycle I $71,31 \%($ good $)$ and cycle $1180,42 \%($ good $)$.
\end{abstract}

Keywords: activity, jigsaw, picture media, result study

\section{PENDAHULUAN}

Pendidikan merupakan upaya penting yang dilakukan secara sadar dan terencana untuk mencerdaskan dan mengembangkan potensi suatu bangsa. Pendidikan juga menjadi tolak ukur suatu bangsa untuk dapat bersaing dalam dunia internasional. Melalui pendidikan suatu bangsa dapat menjadi bangsa yang tangguh, mandiri, berkarakter dan berdaya saing. Sebagai fondasi, pendidikan memberi bekal ilmu pengetahuan bagi siswa, mengembangkan potensi mereka, dan sarana transfer nilai. Menurut Undang-undang Nomor 20 Tahun 2003 tentang Sistem Pendidikan Nasional, Pasal 1 menyatakan bahwa pendidikan adalah usaha sadar dan terencana untuk mewujudkan suasana belajar dan proses pembelajaran agar siswa secara aktif mengembangkan potensi dirinya untuk memiliki kekuatan spiritual keagamaan, pengendalian diri, kepribadian, kecerdasan, akhlak mulia, serta keterampilan yang diperlukan dirinya, masyarakat, bangsa dan negara.

Berdasarkan hasil observasi dan wawancara dengan guru kelas IV SD Negeri 2 Nambahrejo yang dilaksanakan pada tanggal 19 Desembar 2014, didapat keterangan bahwa hasil belajar siswa pada pembelajaran matematika masih rendah atau 
belum mencapai Kriteria Ketuntasan Minimal (KKM) yang telah ditentukan, yaitu 66. Rendahnya hasil belajar siswa dibuktikan dari hasil Ujian Tengah Semester yang telah dilaksanakan pada semester ganjil tahun pelajaran 2014/2015 yaitu, 10 $(41,67 \%)$ dari 24 siswa belum mampu mencapai nilai KKM dan hanya $14(58,33 \%)$ siswa yang sudah mampu mencapai KKM yang telah ditentukan.

Penyebab

rendahnya

persentase siswa dikarenakan terdapat beberapa masalah yang timbul dalam proses pembelajaran antara lain banyak siswa yang berbicara dengan temannya ketika guru sedang menyampaikan materi sehingga pertanyaan-pertanyaan yang disampaikan oleh guru jarang sekali direspon oleh siswa, rendahnya aktivitas dan hasil belajar siswa kelas IV, belum maksimalnya penggunaan model pembelajaran juga membuat suasana belajar menjadi kurang menarik dan bergairah, kurangnya kerjasama siswa dalam kegiatan berkelompok, guru belum maksimal menggunakan media pembelajaran sebagai alat bantu dalam kegiatan pembelajaran, dan guru belum pernah menggunakan variasi model pembelajaran cooperative learning tipe jigsaw dalam pembelajaran di kelas.

Melihat fakta tersebut maka perlu diadakan perbaikan pembelajaran agar hasil belajar siswa dapat meningkat. Upaya perbaikan pembelajaran berkaitan erat dengan inovasi pembelajaran, salah satu bentuk inovasi pembelajaran yaitu menerapkan pembelajaran yang bermakna dan menyenangkan melalui Penelitian Tindakan Kelas (PTK). Menurut Muslikah (2010: 32) PTK adalah suatu bentuk penelitian yang bersifat reflektif dengan melakukan tindakan-tindakan tertentu agar dapat memperbaiki dan meningkatkan praktek-praktek di kelas secara lebih profesional.

PTK perlu menggunakan strategi, pendekatan, model, metode, atau media yang dapat membantu memperbaiki kualitas pembelajaran tersebut. Namun tidak semua strategi, pendekatan, model, metode, atau media dapat digunakan untuk semua mata pelajaran. Seperti teori kognitif yang dipaparkan oleh Piaget (Sumantri, 2007: 1.15) bahwa siswa pada usia 7-11 tahun berada pada tahap operasional konkret, sehingga dalam pembelajaran siswa harus dihadapkan dengan permasalahan yang konkret dan relevan dengan kehidupannya.

Berdasarkan masalah tersebut, penerapan model cooperative learning tipe jigsaw dapat dikatakan sebagai alternatif yang tepat. Menurut Hamdayama (2014: 87) model kooperatif tipe jigsaw merupakan model pembelajaran kooperatif yang mengajarkan siswa belajar dalam kelompok kecil terdiri atas 4-5 orang dengan memperhatikan 
keheterogenan dan bekerja sama positif. Setiap anggota bertanggung jawab untuk mempelajari masalah tertentu dari materi tersebut kepada anggota kelompok yang lain.

Bertolak dari paparan di atas perlu dilakukan perbaikan kualitas pembelajaran melalui penelitian tindakan kelas. Berkaitan dengan penelitian ini, peneliti mengambil judul "Penerapkan Model Cooperative Learning Tipe Jigsaw dengan Media Gambar untuk Meningkatkan Aktivitas dan Hasil Belajar pada Pembelajaran Matematika Siswa Kelas IV SD Negeri 2 Nambahrejo".

Beranjak dari uraian di atas, maka tujuan dari pelaksanaan penelitian ini adalah untuk meningkatkan aktivitas dan hasil belajar siswa kelas IV SD Negeri 2 Nambahrejo melalui penerapan model cooperative learning tipe jigsaw dengan media gambar tahun pelajaran 2014/2015.

Sedangkan manfaat yang diharapkan dari penelitian tentang penerapan model cooperative learning tipe jigsaw dengan media gambar untuk meningkatkan aktivitas dan hasil belajar pada pembelajaran matematika siswa kelas IV SD Negeri 2 Nambahrejo tahun pelajaran 2014/2015 sebagai berikut:

1. Bagi Siswa, dapat meningkatkan aktivitas dan hasil belajar siswa dalam model cooperative learning tipe jigsaw dengan media gambar sehingga dapat mencapai KKM pada pembelajaran matematika siswa kelas IV SD Negeri 2 Nambahrejo tahun pelajaran 2014/2015.

2. Bagi Guru, dapat meningkatkan kualitas pembelajaran di kelasnya, serta menambah dan mengembangkan kemampuan guru dalam menerapkan model cooperative learning tipe jigsaw dengan media gambar dalam kegiatan pembelajaran.

3. Bagi Sekolah, dapat mengharumkan nama baik sekolah, karena hasil belajar siswa jauh lebih meningkat daripada sebelumnya.

4. Bagi Peneliti, dapat menambah pengalaman, ilmu pengetahuan dan penguasaan tentang PTK sehingga kelak akan menjadi seorang guru yang professional.

\section{METODE PENELITIAN}

Penelitian ini menggunakan metode penelitian tindakan kelas (PTK) yang dalam bahasa asing dikenal sebagai classroom action research, yang berarti action research (penelitian dengan tindakan) yang dilakukan di kelas. Mulyasa (2011: 88) mendefinisikan pengertian penelitian tindakan kelas merupakan suatu cara memperbaiki dan meningkatkan profesionalisme guru, karena guru merupakan orang yang paling tahu segala sesuatu yang terjadi dalam pembelajaran.

Penelitian dilaksanakan dua siklus yang 
terdiri dari perencanaan, pelaksanaan, pengamatan, dan refleksi.

Penelitian ini telah dilaksanakan di kelas IV SD Negeri 2 Nambahrejo Kecamatan Kotagajah Kabupaten Lampung Tengah. Penelitian ini dilaksanakan pada semester genap, dengan lama penelitian 5 bulan terhitung dari bulan Desember 2014 - April 2015. Subjek penelitian tindakan kelas adalah siswa dan guru kelas IV SD Negeri 2 Nambahrejo dengan jumlah 24 siswa yang terdiri dari 16 perempuan dan 8 laki-laki.

Teknik pengumpulan data menggunakan teknik tes dan non tes. Teknik tes digunakan untuk mengukur hasil belajar siswa melalui tes formatif. Teknik non tes digunakan untuk mengukur variabel berupa aktivitas siswa, dan kinerja guru melalui lembar observasi. Alat pengumpulan data menggunakan lembar observasi dan soal tes.Teknik analisis data menggunakan analisis kualitatif dan kuantitatif.

\section{HASIL PENELITIAN DAN PEMBAHASAN \\ Deskripsi Awal}

Penelitian ini dilaksanakan di SD Negeri 2 Nambahrejo yang terletak di Kecamatan Kotagajah Kabupaten Lampung Tangah. SD Negeri 2 Nambahrejo memiliki tanah seluas lebih kurang $2.700 \mathrm{~m}^{2}$, terdiri dari 6 ruang kelas, 1 kantor guru, 1 ruang perpustakaan dan 1 ruang UKS. Kelas IV terdiri dari 1 kelas yang terdiri dari 8 siswa laki-laki dan 16 siswa perempuan.

Penelitian ini dilaksanakan pada semester genap tahun pelajaran 2014/2015 dalam dua siklus dengan dua kali pertemuan tiap siklusnya. Perencanaan penelitian pada siklus I secara garis besar peneliti berdiskusi dengan guru kelas IV SD Negeri 2 Nambahrejo tentang penerapan model cooperative learning tipe jigsaw, melakukan analisis kurikulum untuk mengetahui kompetensi inti dan kompetensi dasar yang akan diajarkan dengan menggunakan model cooperative learning tipe jigsaw, menyusun perangkat pembelajaran yaitu: pemetaan, silabus, dan rencana pelaksanaan pembelajaran (RPP), menyiapkan media pembelajaran, menyiapkan instrumen penilaian yang akan digunakan pada kegiatan pembelajaran (lembar observasi penilaian aktivitas siswa dan lembar observasi IPKG guru), dan menyusun alat evaluasi pembelajaran.

\section{Hasil Pelakasanaan Tindakan dan Observasi Siklus I \\ Hasil penelitian yang} diperoleh setelah pelaksanaan pembelajaran ditiap pertemuan mengalami peningkatan. Berikut merupakan rangkuman hasil penelitian yang mendeskripsikan penerapan model cooperative learning tipe jigsaw dengan media 
gambar pada pembelajaran matematika.

Rekapitulasi nilai kinerja guru siklus I menunjukan bahwa guru mendapatkan nilai $70,05 \%$ dengan kategori "baik". Sedangkan hasil analisis data aktivitas belajar siswa memperoleh rata-rata sebesar $62,58 \%$ kategori "aktif".

Sedangkan nilai hasil belajar kognitif siklus I dari 24 siswa kelas IV cukup beragam. Dari nilai rata-rata tiap siswa, dapat diketahui bahwa nilai tertinggi yaitu 100 dan nilai terendah yaitu 50. Berdasarkan penjumlahan nilai rata-rata kelas tiap siswa, didapatkan nilai rata-rata kelas yaitu $71,31 \%$. Jumlah siswa yang tuntas mencapai KKM (66) sebanyak 17 siswa dengan persentase ketuntasan secara klasikal adalah 70,83\% dengan kategori "tinggi".

\section{Refleksi Siklus I}

Berdasarkan hasil observasi pada siklus I, dalam penelitian tindakan kelas ini diperoleh data antara lain:
1) Mengaitkan materi dengan pengetahuan lain yang relevan
2) Menyampaikan materi sesuai dengan hirarki belajar
3) Mengaitkan materi dengan realitas kehidupan
4) Memfasilitasi kegiatan yang memuat komponen eksplorasi, elaborasi, dan konfirmasi
5) Melaksanakan pembelajaran secara runtut
6) Menguasai kelas

7) Meminta setiap kelompok asal membaca dan mendiskusikan subtopik masing-masing dan menetapkan anggota ahli yang akan bergabung dalam kelompok ahli

8) Meminta anggota ahli dari masing-masing kelompok berkumpul dan mengintegrasikan semua subtopik yang telah dibagikan sesuai dengan banyaknya kelompok

9) Melaksanakan pembelajaran yang memungkinkan tumbuhnya kebiasaan yang positif (nurturant effect)

10) Melaksanakan pembelajaran dengan menggunakan model cooperative learning tipe jigsaw sesuai dengan alokasi waktu yang direncanakan

11) Menunjukkan keterampilan dalam penggunaan media

12) Menghasilkan pesan yang menarik

13) Menggunakan media secara efektif dan efisien

14) Melibatkan siswa dalam pemanfaatan media

15) Menumbuhkan partisipasi aktif siswa dalam pembelajaran

16) Memfasilitasi terjadinya interaksi guru, siswa, dan sumber belajar

\section{Hasil Pelakasanaan Tindakan dan Observasi Siklus II \\ Setelah dilakukan} pembelajaran di siklus II diperoleh rata-rata kinerja guru yaitu sebesar $82,29 \%$ dengan kategori "baik". 
Sedangkan hasil analisis data aktivtas siswa memperoleh ratarata yaitu $81,50 \%$ kategori "sangat aktif".

Nilai rata-rata hasil belajar kognitif tiap siswa, dapat diketahui bahwa nilai tertinggi yaitu 100 dan nilai terendah yaitu 45 . Berdasarkan penjumlahan nilai seluruh siswa, didapatkan nilai rata-rata kelas yaitu 91,67\%. Jumlah siswa yang tuntas mencapai KKM (66) sebanyak 22 siswa dengan persentase ketuntasan secara klasikal adalah $91,67 \%$ dengan kategori "sangat tinggi".

\section{Refleksi Siklus II}

Berdasarkan penelitian yang telah dilakukan terhadap pelaksanaan siklus II, pada pembelajaran matematika dengan menerapkan model cooperative learning tipe jigsaw telah memenuhi indikator keberhasilan yang telah ditentukan, yaitu:

1) Terdapat peningkatan aktivitas dan hasil belajar matematika siswa kelas IV SDN 2 Nambahrejo pada setiap siklusnya.

2) Pada akhir penelitian siswa dinyatakan tuntas apabila siswa yang mencapai KKM 66 mencapai $\geq 75 \%$ dari jumlah siswa pada kelas IV yang diteliti yaitu 24 siswa.

Hal ini dibuktikan dengan presentase rata-rata aktivitas belajar siswa pada siklus II sebesar $81,50 \%$. Kemudian presentase hasil belajar pada siklus II sebesar $80,42 \%$. Sedangkan presentase rata-rata kinerja guru pada siklus II sebesar $82,29 \%$.

Berdasarkan hasil pada siklus II maka tindakan pada siklus penelitian dihentikan, karena hasil yang diharapkan sudah tercapai yaitu aktivitas dan hasil belajar siswa sudah mengalami peningkatan dari siklus I sampai dengan siklus II.

\section{Pembahasan}

1) Kinerja Guru

Berdasarkan hasil observasi yang dilakukan observer (teman sejawat) menggunakan lembar instrumen.

Pelaksanaan pembelajaran menggunakan model cooperative learning tipe jigsaw dan media gambar sudah berjalan dengan baik, dapat dilihat pada tabel berikut.

Tabel 1. Rekapitulasi nilai kinerja guru siklus I dan siklus II

\begin{tabular}{|c|l|c|c|}
\hline No & \multicolumn{1}{|c|}{ Aspek } & Siklus I & Siklus II \\
\hline 1 & Nilai rata-rata & $70,05 \%$ & $82,29 \%$ \\
\hline 2 & Kategori & Baik & Sangat Baik \\
\hline 3 & Peningkatan nilai rata-rata & \multicolumn{2}{|c|}{$12,24 \%$} \\
\hline
\end{tabular}

Untuk melihat lebih jelas terjadinya peningkatan kinerja guru, maka peneliti menyajikan gambar diagram berikut: 
ISSN 2442-5419 Vol. 4, No. 2 (2015) 95-105

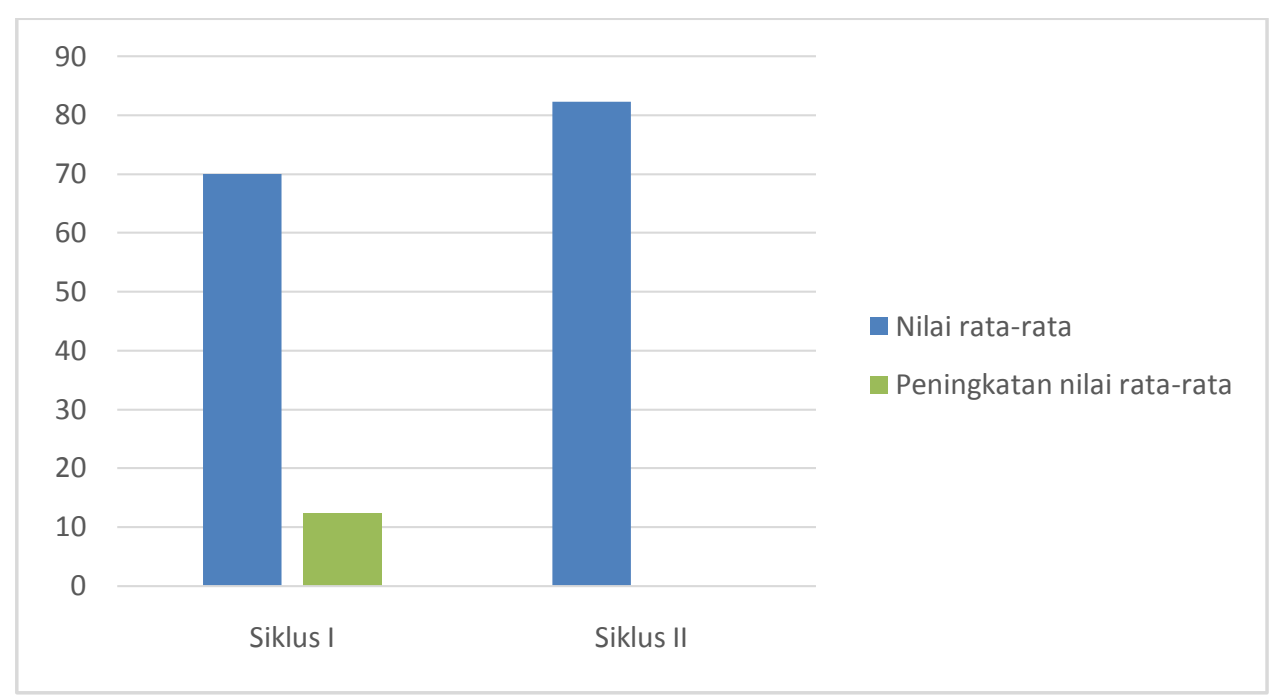

Gambar 1. Nilai Kinerja Guru per-Siklus

Berdasarkan tabel 1 dan gambar 1 dapat diamati bahwa kinerja guru mengalami peningkatan pada tiap siklus pembelajaran yang dilaksanakan. Rata-rata kinerja guru pada siklus I sebesar 70,05\% dengan kategori kinerja baik dan meningkat pada siklus II menjadi 82,29\% dengan kategori sangat baik. Hal tersebut menunjukkan bahwa terjadi peningkatan rata-rata kinerja guru sebesar 12,24\%. Hal ini menunjukkan bahwa kinerja guru pada saat pembelajaran berlangsung mengalami peningkatan di setiap siklusnya sebagaimana digambarkan pada grafik yang terus meningkat.

2) Aktivitas Belajar Siswa

Analisis data terhadap hasil penelitian setelah mengikuti pembelajaran dengan menggunakan model cooperative learning tipe jigsaw dengan media gambar pada SD Negeri 2 Nambahrejo adalah sebagai berikut.

Tabel 2. Rekapitulasi persentase aktivitas siswa siklus I dan siklus II

\begin{tabular}{|c|l|c|c|c|c|}
\hline \multirow{2}{*}{ No } & \multirow{2}{*}{ Aspek } & \multicolumn{2}{c|}{ Siklus 1 } & \multicolumn{2}{c|}{ Siklus II } \\
\cline { 3 - 6 } & & Pert 1 & Pert 2 & Pert I & Pert 2 \\
\hline 1 & Nilai & $61 \%$ & $64,72 \%$ & $79 \%$ & $84 \%$ \\
\hline 2 & Rata-rata & \multicolumn{2}{|c|}{$62,58 \%$} & \multicolumn{2}{c|}{$81,50 \%$} \\
\hline 3 & Kriteria & \multicolumn{2}{|c|}{ Aktif } & Sangat Aktif \\
\hline 4 & Peningkatan Rata-rata & \multicolumn{3}{|c}{$18,92 \%$} \\
\hline
\end{tabular}


Peningkatan aktivitas siswa diamati pada tabel sebagai dalam proses pembelajaran dapat berikut.

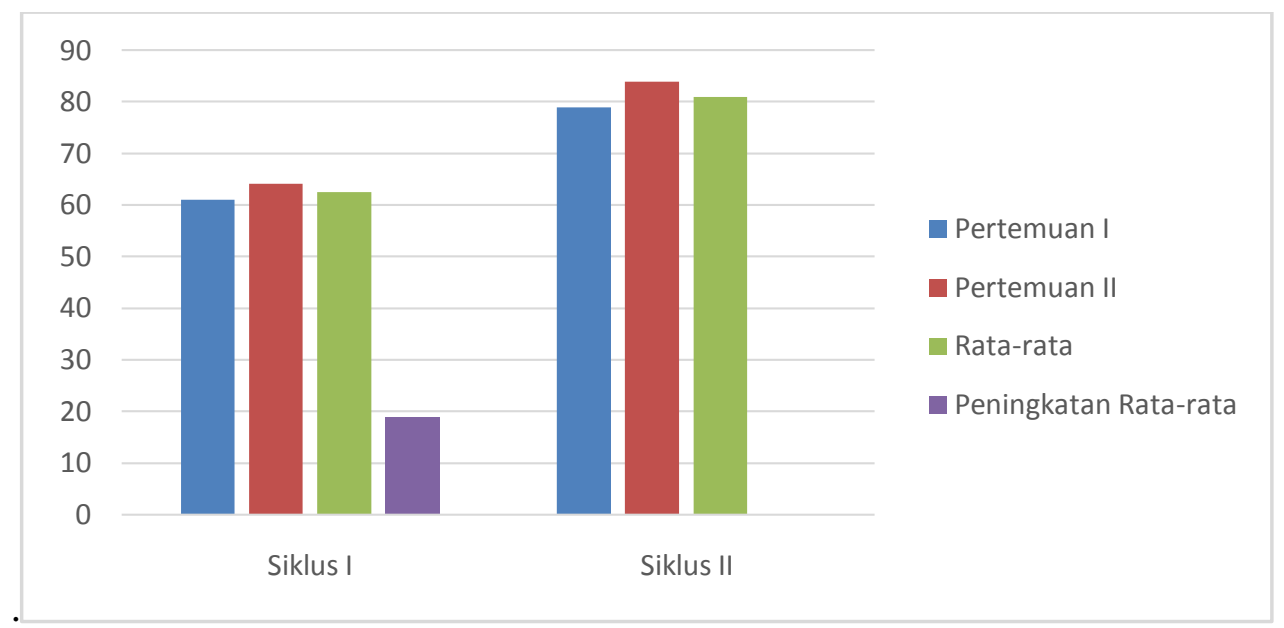

Gambar 2. Persentase Aktivitas Belajar Siswa per-Siklus.

Berdasarkan tabel 2 dan gambar 2 diketahui bahwa aktivitas siswa mengalami peningkatan disetiap siklus. Persentase aktivitas klasikal diperoleh melalui rata-rata kemunculan indikator dalam pembelajaran. Pada siklus I memperoleh nilai rata-rata aktivitas klasikal sebesar $62,58 \%$ dengan kategori "aktif" dan siklus II mencapai $81,50 \%$ dengan kategori "sangat aktif". Presentase aktivitas siswa mengalami peningkatan sebesar $18,92 \%$.

Berdasarkan uraian di atas, peneliti mengambil kesimpulan bahwa peningkatan yang ditunjukkan dalam aktivitas belajar siswa membuktikan bahwa model cooperative learning tipe jigsaw dan media gambar dapat meningkatkan aktivitas atau kegiatan belajar secara optimal.
Hal tersebut sejalan dengan pendapat Kunandar (2011: 277) aktivitas belajar adalah keterlibatan siswa dalam bentuk sikap, pikiran, perhatian, dan aktivitas dalam kegiatan pembelajaran guna menunjang keberhasilan proses belajar mengajar dan memperoleh manfaat.

\section{3) Hasil Belajar Siswa}

Hasil belajar siswa yang diperoleh dari pelaksanaan tes formatif siklus I dan II mengalami peningkatan disetiap siklusnya. Hal ini dapat dilihat antara hasil belajar siswa pada siklus I dan II terdapat kenaikan jumlah siswa yang tuntas dan penurunan jumlah siswa yang belum tuntas. Hasil belajar siswa pada siklus I dan II dapat dilihat pada tabel berikut. 
ISSN 2442-5419 Vol. 4, No. 2 (2015) 95-105

Tabel 3. Rekapitulasi hasil belajar siswa siklus I dan siklus II

\begin{tabular}{|c|l|c|c|}
\hline No. & Ketuntasan Hasil Belajar Siswa & Siklus I & Siklus II \\
\hline 1. & Nilai rata-rata & $71,31 \%$ & $80,42 \%$ \\
\hline 2. & Peningkatan Rata-rata & \multicolumn{2}{|c|}{$9,11 \%$} \\
\hline 3. & Persentase Ketuntasan & $70,83 \%$ & $91,67 \%$ \\
\hline 4 & Peningkatan Persentase & \multicolumn{2}{|c|}{$20,84 \%$} \\
\hline
\end{tabular}

Peningkatan persentase hasil belajar kognitif siswa dalam siklus penelitian dapat juga ditunjukan pada grafik berikut.

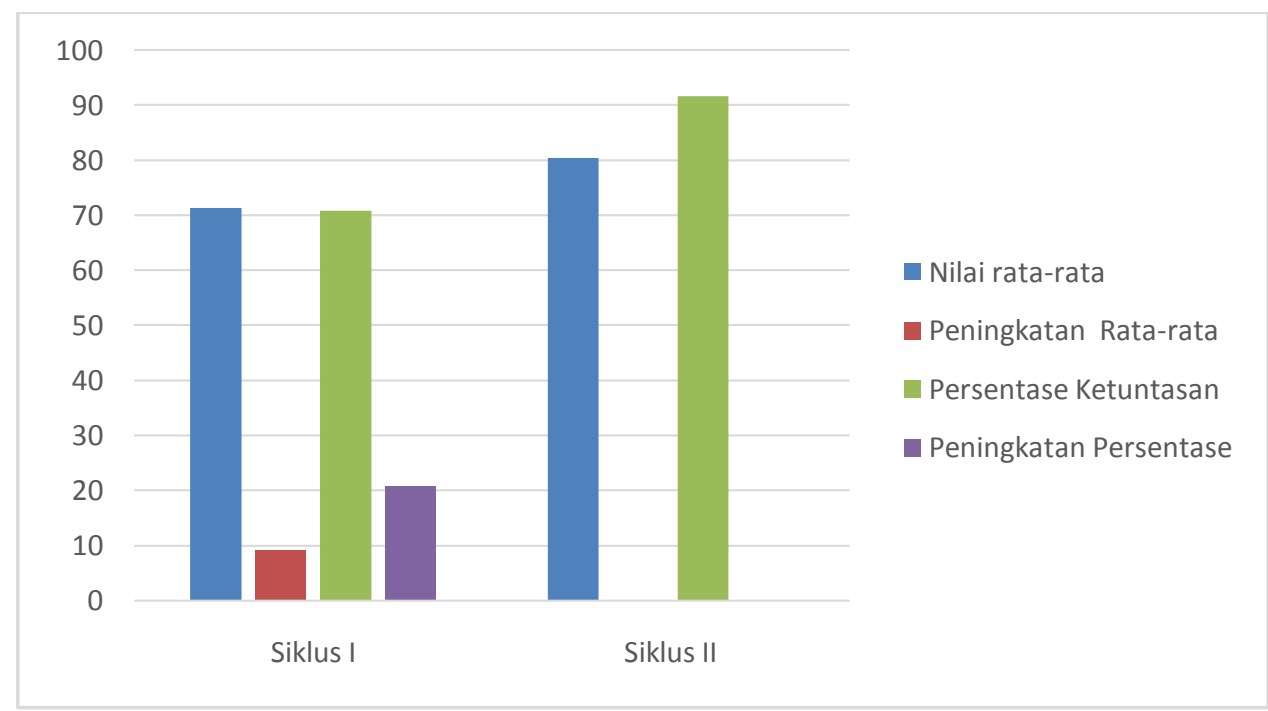

Gambar 3. Rekapitulasi Hasil Belajar Kognitif per-Siklus.

Pada siklus I rata-rata nilai hasil belajar siswa sebesar $71,31 \%$ dengan persentase ketuntasan sebesar $70,83 \%$ sedangkan pada siklus II rata - rata meningkat sebesar $9,11 \%$ sehingga menjadi $80,42 \%$ dan persentase ketuntasan siswa secara klasikal terjadi peningkatan angka persentase menjadi 91,67\%. Peningkatan angka persentase sebesar $20,84 \%$ ini membuktikan bahwa hasil penelitian pada siklus II sudah mencapai indikator keberhasilan yang telah ditentukan.

Berdasarkan hasil penelitian menunjukkan bahwa melalui penerapan model cooperative learning tipe jigsaw dengan media gambar dapat meningkatkan aktivitas dan hasil belajar siswa, khususnya pada kelas IV SD Negeri 2 Nambahrejo tahun pelajaran 2014/2015. Hal ini 
sesuai dengan pendapat Isjoni (2007: 54) bahwa pembelajaran cooperative learning tipe jigsaw merupakan salah satu tipe pembelajaran kooperatif yang mendorong siswa aktif dan saling membantu dalam menguasai materi pelajaran untuk mencapai prestasi yang maksimal.

\section{KESIMPULAN DAN SARAN Kesimpulan}

Berdasarkan penelitian tindakan kelas yang dilakukan terhadap siswa kelas IV SD Negeri 2 Nambahrejo Kecamatan Trimurjo pada pembelajaran mamatematika dengan menerapkan model cooperative learning tipe jigsaw dan media gambar dapat disimpulkan sebagai berikut.

1. Penerapan model cooperative learning tipe jigsaw dengan media gambar sesuai langkahlangkah yang yang tepat dalam pembelajaran matematika dapat meningkatkan aktivitas belajar siswa. Hal ini dibuktikan dengan adanya peningkatan rata-rata tiap siklusnya. Ratarata siklus I sebesar $62,58 \%$ dengan kategori "aktif", meningkat pada siklus II sebesar $81,50 \%$ termasuk kategori "sangat aktif", dengan peningkatan sebesar $18,92 \%$.

2. Penerapan model cooperative learning tipe jigsaw dan media gambar dalam pembelajaran matematika dapat meningkatkan hasil belajar siswa kelas IV SD Negeri 2 Nambahrejo yang dapat diketahui dari nilai rata-rata hasil belajar siswa dan persentase ketuntasan hasil belajar siswa secara klasikal. Nilai rata-rata hasil belajar siswa pada siklus I sebanyak 17 siswa tuntas $(70,83 \%)$ dengan rata-rata $71,31 \%$. Siklus II sebanyak 22 siswa tuntas $(91,67 \%)$ dengan rata-rata $80,42 \%$. Peningkatan persentase ketuntasan hasil belajar sebesar 20,84\% dan peningkatan rata-rata sebesar $9,11 \%$.

\section{Saran}

Berdasarkan kesimpulan yang telah diuraikan di atas, peneliti memberikan saran antara lain:

1. Bagi siswa, dapat bertanggung jawab akan tugas yang diberikan guru baik tugas individu maupun kelompok dan dapat bekerja sama dalam tim belajar di kelompok asal maupun kelompok ahli.

2. Bagi guru, dapat memfasilitasi dan membimbing siswa dalam kelompok saat mempresentasikan hasil diskusi sehingga ide-ide dapat menyebar.

3. Bagi sekolah, dapat mengoptimalkan sarana dan prasarana serta penyediaan alat dan media sebagai penunjang yang mendukung pelaksanaan pembelajaran agar siswa lebih aktif dan termotivasi dalam 
ISSN 2442-5419 Vol. 4, No. 2 (2015) 95-105

penerapan tipe jigsaw dan media gambar.

4. Bagi peneliti lanjutan, dapat mengembangkan dan menjadi sumber perbaikan pembelajaran dengan menerapkan model pembelajaran sejenis pada kelas lainatau pada materi lain.

\section{DAFTAR PUSTAKA}

Hamdayama, J. 2014. Model dan

Metode Pembelajaran

Kreatif dan Berkarakter.

Bandung: Ghalia Indonesia.

Isjoni. 2007. Cooperative Learning. Alfabeta. Bandung.

Kunandar. 2011. Penelitian

Tindakan Kelas. Rajawali Pers. Jakarta.

Mulyasa. 2011. Praktik Penelitian

Tindakan Kelas. Bandung:

PT Remaja Rosdakarya.

Muslikah, 2010. Sukses Profesi

Guru Dengan Penelitian

Tindakan Kelas.

Interprebook. Yogyakarta.

Sumantri, Mulyani \& Nana Syaodih. 2007. Materi

Pokok Perkembangan

Peserta Didik. Universitas

Terbuka. Jakarta. 